\title{
SISTEM PENDUKUNG KEPUTUSAN PENENTUAN RESEP MAKANAN BERDASARKAN BAHAN MAKANAN MENGGUNAKAN METODE TOPSIS
}

\author{
Budanis Dwi Meilani ${ }^{1)}$, Adimas Wisnu Wardana ${ }^{2)}$ \\ 1), 2) Jurusan Sistem Informas, Fakultas Teknologi Informasi, Institut Teknologi Adhi Tama Surabaya \\ Email : $\underline{\text { budanis@itats.ac.id }}{ }^{1)}$, wisnuwardana.adimas@gmail.com ${ }^{2)}$
}

\begin{abstract}
Abstrak
Pada zaman sekarang ini banyak orang yang memiliki hobi memasak. Dengan memasak seseorang dapat menghidangkan beraneka ragam makanan. Bahan makanan serta cara mengolah bahan makanan dalam suatu makanan dapat dilihat pada resep makanan. Resep makanan merupakan panduan bagi seseorang dalam mengolah bahan makanan menjadi hidangan yang dapat disajikan. Dengan semakin banyaknya resep makanan yang ada, seseorang akan lebih mudah untuk mencari resep melalui media infomasi internet. Oleh karena itu, sistem pendukung keputusan berbasis web yang dapat menentukan resep makanan sesuai kebutuhan pengguna diperlukan. Pengguna akan memasukkan kriteria yang dibutuhkan seperti bahan makanan, tingkat kesulitan, dan waktu memasak. Dengan metode Technique for Order Preference by Similarity to Ideal Solution (TOPSIS) yang memiliki konsep dimana alternatif terpilih merupakan alternatif yang memiliki jarak terkecil dari solusi ideal positif dan jarak terbesar dari solusi ideal negatif. Data kriteria yang telah dimasukkan ke dalam sistem oleh pengguna akan dihitung. Sistem ini mampu memberikan rekomendasi resep masakan sesuai keinginan pengguna. Dari 10 data yang telah diuji coba dalam implementasi sistem, 8 data dinyatakan sesuai sedangkan 2 data dinyatakan tidak sesuai, sehingga tingkat akurasi dari sistem ini sebesar $80 \%$.
\end{abstract}

Kata Kunci : Sistem Pendukung Keputusan, TOPSIS, Resep Makanan, Internet

\begin{abstract}
In this day and age many people have a hobby of cooking. By cooking someone can serve a wide variety of foods. Food ingredients and how to process food ingredients in a food can be seen in food recipes. Food recipes are a guide for someone to process food into dishes that can be served. As more food recipes are available, one will find it easier to search for recipes through internet information media. Therefore, a web-based decision support system that can determine food recipes according to user needs is needed. The user will enter the required criteria such as food ingredients, difficulty level, and cooking time. With the Technique for Order Preference by Similarity to Ideal Solution (TOPSIS) method that has a concept where the chosen alternative is an alternative that has the smallest distance from the positive ideal solution and the biggest distance from the negative ideal solution. Criteria data that has been entered into the system by users will be calculated. This system is able to provide recommendations for cooking recipes according to the user's wishes. Of the 10 data that have been tested in the implementation of the system, 8 data are declared appropriate while 2 data are declared inaccurate, so the accuracy of this system is $80 \%$.
\end{abstract}

Keywords : Decision Support System, TOPSIS, Food Recipe, Internet

\section{PENDAHULUAN}

Pada zaman sekarang ini banyak orang memiliki hobi memasak. Dengan memasak seseorang dapat menghidangkan beraneka ragam makanan untuk kebutuhan makanan di rumah. Bahan makanan dan cara mengolah bahan makanan dalam suatu masakan dapat dilihat pada resep makanan. Resep adalah kumpulan resep dari segala penjuru dunia, informasi mengenai bahanbahan masakan, cara mengolahnya serta hal-hal lainnya yang berhubungan dengan masakan [1]. Resep makanan merupakan panduan bagi seseorang dalam mengolah bahan makanan menjadi hidangan yang dapat disajikan. Dengan semakin banyaknya variasi resep makanan yang ada, akan lebih mudah untuk melakukan pencarian resep makanan melalui media informasi internet. Pencarian resep masakan pada resep digital saat ini dilakukan secara manual dengan cara 
membandingkan resep-resep yang dicari dengan resep yang sesuai dengan kebutuhan pengambil keputusan.[2].

Hal ini dikarenakan kurangnya pengetahuan untuk dapat mengolah bahan makanan sendiri. Padahal seringkali bahan makanan yang siap olah telah tersedia di rumah. Oleh karena itu, diperlukan aplikasi berbasis web yang dapat menentukan resep makanan berdasarkan bahan makanan, tingkat kesulitan, waktu memasak dan jumlah peralatan memasak sesuai dengan kebutuhan pengguna.

Metode yang digunakan dalam aplikasi ini adalah metode TOPSIS (Technique Order Preference by Similarity to Ideal Solution). Metode tersebut dipilih karena TOPSIS merupakan suatu bentuk metode pendukung keputusan yang didasarkan pada konsep bahwa alternatif yang terbaik tidak hanya memiliki jarak terpendek dari solusi ideal positif tetapi juga memiliki jarak terpanjang dari solusi ideal negatif yang dalam hal ini akan memberikan rekomendasi resep makanan yang sesuai dengan kriteria yang diinginkan.

\section{DASAR TEORI}

Konsep Decision Support System pertama kali dinyatakan pada tahun 1970 dengan istilah "Management Decision System". Setelah pernyataan tersebut, beberapa perusahaan dan perguruan tinggi melakukan riset dan mengembangkan konsep Decision Support System. [3]. Pada dasarnya DSS dirancang untuk mendukung seluruh tahap pengambilan keputusan mulai dari mengidentifikasi masalah, memilih data yang relevan, menentukan pendekatan yang digunakan dalam proses pengambilan keputusan, sampai mengevaluasi pemilihan alternatif. [4].

Karakteristik dan Kemampuan Sistem Pendukung Keputusan diantaranya adalah sebagai berikut: mendukung seluruh kegiatan organisasi, mendukung beberapa keputusan yang saling berinteraksi, dapat digunakan berulang kali dan bersifat konstan, terdapat dua komponen utama, yaitu data dan model, menggunakan baik data eksternal maupun internal, Memiliki kemampuan what-if analysis dan goal seeking analysis, Menggunakan beberapa model kuantitatif. [5].

Metode TOPSIS didasarkan pada konsep bahwa alternatif terpilih yang terbaik tidak hanya memiliki jarak terpendek dari solusi ideal positif tetapi juga memiliki jarak terpanjang dari solusi ideal negatif. Solusi ideal adalah solusi yang semua nilai kriterianya sesuai dengan nilai kriteria maksimal. Sedangkan solusi ideal negatif adalah solusi yang semua nilai kriterianya sesuai dengan nilai kriteria minimal. [6]. Metode ini tidak hanya memberikan solusi terbaik tetapi juga menunjukkan solusi terburuk.

Kini internet identik dengan web, karena kepopuleran web sebagai standar tampilan pada layanan-layanan yang ada di internet. Dari awalnya sebagai penyedia informasi, internet juga digunakan untuk komunikasi seperti email, chat, dan transaksi bisnis (commerce).[7].

Bagan alir (flowchart) adalah bagan (chart) yang menunjukan hasil (flow) di dalam program atau prosedur sistem secara logika. Flowchart digunakan sebagai alat bantu komunikasi dan untuk dokumentasi. [8].

Diagram konteks merupakan tingkatan tertinggi dalam suatu diagram aliran data yang hanya memuat satu proses dan menunjukan secara keseluruhan. Dalam diagram konteks digambarkan semua entitas eksternal berikut aliran - aliran datanya. Dalam diagram ini tidak memuat adanya bentuk penyimpanan data dan diagram ini ditampilkan dalam bentuk yang paling sederhana. Diagram konteks mewakili sejumlah karakteristik penting dari suatu sistem [9].

Rensis Likert mengembangkan sebuah skala untuk mengukur sikap masyarakat di tahun 1932 yang sekarang terkenal dengan nama skala Likert. Skala Likert dapat digunakan untuk mengukur sikap, pendapat, dan persepsi seseorang atau sekelompok orang mengenai suatu gejala. Jawaban setiap item instrumen yang menggunakan skala Likert mempunyai gradasi dari sangat rendah sampai sangat tinggi dengan nilai 1 sampai 5. [10].

\section{METODOLOGI PENELITIAN}

Sistem yang akan dibangun merupakan sistem yang menggunakan metode TOPSIS dengan beberapa kebutuhan sebagai berikut :

1. Kebutuhan Input 
Input kriteria dari data-data resep makanan yang terdiri dari bahan makanan, tingkat kesulitan, waktu memasak dan jumlah peralatan yang digunakan.

2. Kebutuhan Output

Output sistem berupa rekomendasi resep makanan yang sesuai dengan kriteria yang diinginkan oleh pengguna.

\section{Flowchart Sistem}

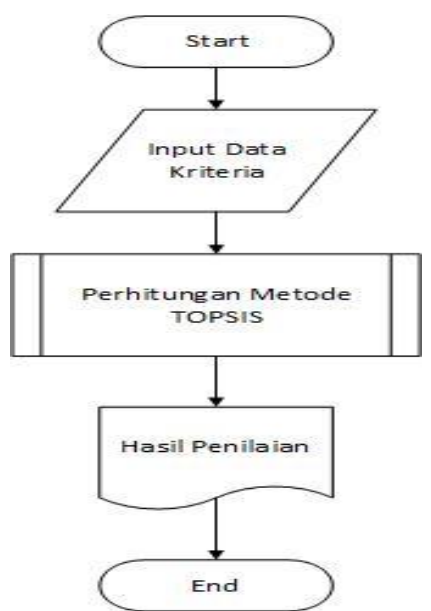

Flowchart Metode TOPSIS

Gambar 1. Flowchart Sistem
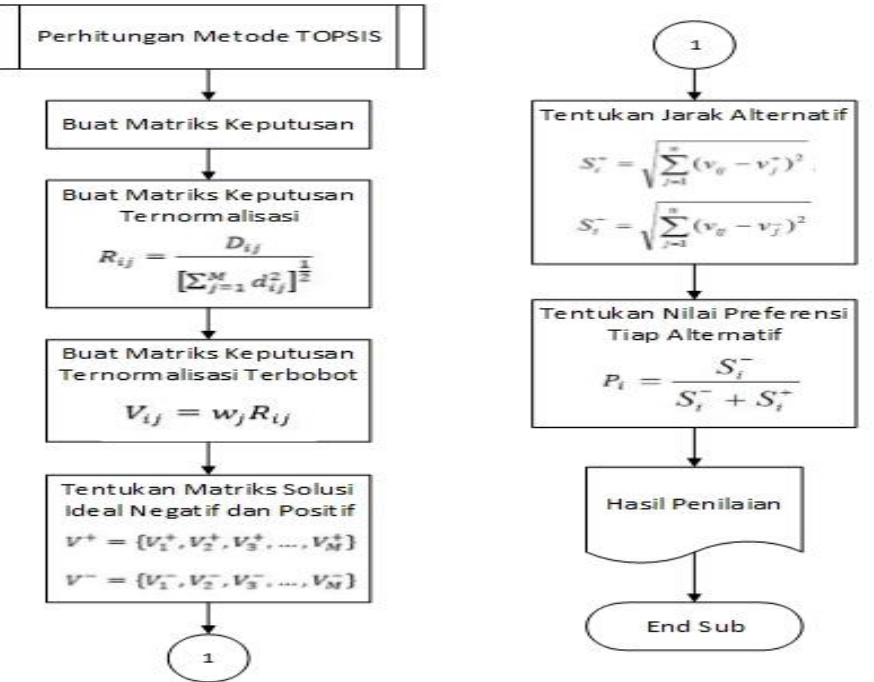

Gambar 2. Flowchart Metode TOPSIS

TOPSIS dalam prosesnya memerlukan kriteria yang akan dijadikan bahan perhitungan. Dari tiap-tiap kriteria tersebut akan ditentukan nilai atau bobotnya sesuai dengan tingkat kepentingan dari setiap kriteria. Penilaian atau pembobotan kriteria menggunakan sebuah acuan salah satunya adalah skala Likert. Data Kriteria dalam aplikasi ini menggunakan 4 data kriteria yang sudah ditentukan nilai atau bobotnya berdasarkan tingkat kepentingannya seperti pada tabel 1 berikut :

Tabel 1. Pembobotan Kriteria

\begin{tabular}{|c|c|c|}
\hline Simbol & Kriteria & Nilai \\
\hline K1 & Bahanan Makanan & 5 \\
\hline K2 & Tingkat Kesulitan & 4 \\
\hline K3 & Waktu Memasak & 5 \\
\hline K4 & Jumlah Peralatan yang Digunakan & 5 \\
\hline
\end{tabular}

Setiap data kriteria akan ditentukan bobotnya untuk proses perhitungan. Berikut penjelasan tentang kriteria - kriteria yang dibutuhkan : 


\section{Kriteria Bahan Makanan}

Kriteria bahan makanan merupakan salah satu syarat yang dibutuhkan sebagai dasar rekomendasi. Berdasarkan hasil survei dan studi literatur resep masakan, bahan makanan merupakan komponen yang paling penting dalam suatu resep makanan. Berikut penjelasan terhadap penilaian bobot bahan makanan pada tabel 2 .

Tabel 2. Bobot Kriteria Bahan Makanan

\begin{tabular}{|l|c|}
\hline \multicolumn{1}{|c|}{ Bahan Makanan } & Nilai \\
\hline Bahan makanan pada resep sesuai dengan bahan makanan yang dimiliki & 5 \\
\hline Bahanan makanan pada resep kurang 1 jenis dari bahan makanan yang dimiliki & 4 \\
\hline Bahanan makanan pada resep kurang 2 jenis dari bahan makanan yang dimiliki & 3 \\
\hline Bahanan makanan pada resep kurang 3 jenis dari bahan makanan yang dimiliki & 2 \\
\hline $\begin{array}{l}\text { Bahanan makanan pada resep kurang 4 jenis atau lebih dari bahan makanan yang } \\
\text { dimiliki }\end{array}$ & 1 \\
\hline
\end{tabular}

2. Kriteria Tingkat Kesulitan

Kriteria tingkat kesulitan merupakan salah satu syarat yang dibutuhkan sebagai dasar rekomendasi. Berdasarkan hasil survei resep makanan, tingkat kesulitan terbagi menjadi tiga tingkatan yaitu mudah, sedang, dan susah. Berikut penjelasan terhadap penilaian bobot tingkat kesulitan pada tabel 3 .

Tabel 3. Bobot Kriteria Tingkat Kesulitan

\section{Kriteria Waktu Memasak}

\begin{tabular}{|c|c|}
\hline Tingkat Kesulitan & Nilai \\
\hline Mudah & 5 \\
\hline Sedang & 3 \\
\hline Susah & 1 \\
\hline
\end{tabular}

Kriteria waktu memasak merupakan salah satu syarat yang dibutuhkan sebagai dasar rekomendasi. Waktu memasak disini merupakan lamanya waktu yang dibutuhkan untuk mengolah bahan makanan menjadi makanan siap saji pada suatu resep makanan. Berikut penjelasan terhadap penilaian bobot tingkat kesulitan pada tabel 4 .

Tabel 4. Bobot Kriteria Waktu Memasak

4. Kriteria Jumlah Peralatan yang Digunakan

\begin{tabular}{|c|c|}
\hline Waktu Memasak & Nilai \\
\hline$<=15$ Menit & 5 \\
\hline $16-30$ Menit & 4 \\
\hline $31-45$ Menit & 3 \\
\hline $46-60$ Menit & 2 \\
\hline$>60$ Menit & 1 \\
\hline
\end{tabular}

Kriteria jumlah peralatan yang digunakan merupakan salah satu syarat yang dibutuhkan sebagai dasar rekomendasi. Berikut penjelasan terhadap penilaian bobot tingkat kesulitan pada tabel 5 .

Tabel 5. Bobot Kriteria Jumlah Peralatan yang Digunakan

\begin{tabular}{|c|c|}
\hline Jumlah Peralatan yang Digunakan & Nilai \\
\hline 1 Alat & 5 \\
\hline 2 Alat & 4 \\
\hline 3 Alat & 3 \\
\hline 4 Alat & 2 \\
\hline >= 5 Alat & 1 \\
\hline
\end{tabular}

Sebagai contoh ada seorang ibu rumah tangga yang ingin membuat suatu makanan dengan kriteria yang diinginkan seperti pada tabel 6.

Tabel 6. Data Kriteria Pengguna 


\begin{tabular}{|c|c|c|}
\hline Simbol & Kriteria & Keterangan \\
\hline K1 & Bahan Makanan Tersedia & $\begin{array}{c}\text { Beras, nasi, mentega, ayam, cabai, kunyit, } \\
\text { bawang, garam, merica }\end{array}$ \\
\hline K2 & Tingkat Kesulitan yang Dipilih & Mudah \\
\hline K3 & Waktu Memasak yang Dipilih & $<=60$ Menit \\
\hline K4 & Jumlah Peralatan yang Digunakan & $<=5$ Alat \\
\hline
\end{tabular}

Berikut terdapat beberapa contoh alternatif dapat dilihat pada tabel 7.

Tabel 7. Data Alternatif

\begin{tabular}{|c|c|c|c|c|c|}
\hline Simbol & Alternatif & K1 & K2 & K3 & K4 \\
\hline A1 & $\begin{array}{c}\text { Nasi Goreng } \\
\text { Ayam }\end{array}$ & $\begin{array}{c}\text { Mentega/ minyak goreng, nasi, ayam, } \\
\text { bawang, garam, merica }\end{array}$ & Mudah & 15 Menit & 1 \\
\hline A2 & $\begin{array}{c}\text { Nasi Bakar } \\
\text { Ayam }\end{array}$ & $\begin{array}{c}\text { Nasi, ayam, cabai, bawang, merica, } \\
\text { garam, daun pisang }\end{array}$ & Mudah & 25 Menit & 1 \\
\hline A3 & Nasi Uduk & Beras, santan, daun pandan, garam & Sedang & 35 Menit & 1 \\
\hline A4 & Nasi Kuning & $\begin{array}{c}\text { Beras, santan, daun salam, kunyit, } \\
\text { bawang }\end{array}$ & Mudah & 35 Menit & 1 \\
\hline
\end{tabular}

Langkah-langkah perhitungan menggunakan metode TOPSIS :

1. Membuat matriks keputusan yang ternormalisasi.

Matriks keputusan yang dibentuk sebagai berikut :

$\mathrm{D}=\left\{\begin{array}{llll}5 & 5 & 5 & 5 \\ 5 & 5 & 4 & 5 \\ 4 & 3 & 3 & 5 \\ 4 & 5 & 3 & 5\end{array}\right\}$

Proses normalisasi matriks keputusan :

$\mathrm{R}_{11}=\frac{5}{\sqrt{5^{2}+5^{2}+4^{2}+4^{2}}}=\frac{5}{9,0554}=0,5522$

$\mathrm{R}_{12}=\frac{5}{\sqrt{5^{2}+5^{2}+3^{2}+5^{2}}}=\frac{5}{9,1652}=0,5455$

$\mathrm{R}_{13}=\frac{5}{\sqrt{5^{2}+4^{2}+3^{2}+3^{2}}}=\frac{5}{7,6811}=0,6509$

$\mathrm{R}_{14}=\frac{5}{\sqrt{5^{2}+5^{2}+5^{2}+5^{2}}}=\frac{5}{10}=0,5$

Dengan cara yang sama diperoleh matriks keputusan sebagai berikut :

$R=\left\{\begin{array}{llll}0,5522 & 0,5455 & 0,6509 & 0,5 \\ 0,5522 & 0,5455 & 0,5208 & 0,5 \\ 0,4417 & 0,3273 & 0,3906 & 0,5 \\ 0,4417 & 0,5455 & 0,3906 & 0,5\end{array}\right\}$

2. Membuat matriks normalisasi terbobot. Bobot yang diberikan DM sebagai berikut: $\mathrm{W}=$ $(5,4,5,5)$

Proses normalisasi matriks terbobot:

$\mathrm{V}_{11}=5 \times 0,5522=2,7608$

$\mathrm{V}_{12}=4 \times 0,5455=2,1822$

$\mathrm{V}_{13}=5 \times 0,6509=3,2547$

$\mathrm{V}_{14}=5 \times 0,5=2,5$

Dengan cara yang sama diperoleh matriks normalisasi terbobot sebagai berikut : 


$$
V=\left\{\begin{array}{cccc}
2,7608 & 02,1822 & 3,2547 & 2,5 \\
2,7608 & 02,1822 & 2,6038 & 2,5 \\
2,2086 & 1,3093 & 1,9528 & 2,5 \\
2,2086 & 02,1822 & 01,9528 & 2,5
\end{array}\right\}
$$

3. Menentukan solusi ideal positif dan solusi ideal negatif.

Solusi ideal positif dihitung sebagai berikut :

$\mathrm{V}_{1}{ }^{+}=\max (2,7608 ; 2,1822 ; 3,2547 ; 2,5)=2,7608$

Sedangkan, solusi ideal negatif dihitung sebagai berikut :

$\mathrm{V}_{1}^{+}=\min (2,2088 ; 1,3093 ; 1,9528 ; 2,5)=1,2093$

4. Menentukan jarak setiap alternatif dengan solusi ideal positif dan solusi ideal negatif.

Jarak terhadap solusi ideal positif dihitung sebagai berkut :

$\mathrm{S}_{1}{ }^{+}=\left((2,7608-2,7608)^{2}+(2,1822-2,1822)^{2}+(3,2547-3,2547)^{2}+(2,5-2,5)^{2}\right)^{1 / 2}=0$

$\mathrm{S}_{2}{ }^{+}=\left((2,7608-2,7608)^{2}+(2,1822-2,1822)^{2}+(32,6038-3,2547)^{2}+(2,5-2,5)^{2}\right)^{1 / 2}=0,6509$

$\mathrm{S}_{3}{ }^{+}=\left((2,2086-2,7608)^{2}+(1,3093-2,1822)^{2}+(1,9528-3,2547)^{2}+(2,5-2,5)^{2}\right)^{1 / 2}=1,6618$

$\mathrm{S}_{4}^{+}=\left((2,2086-2,7608)^{2}+(2,1822-2,1822)^{2}+(1,9528-3,2547)^{2}+(2,5-2,5)^{2}\right)^{1 / 2}=1,4141$

Sedangkan jarak terhadap solusi ideal negatif dihitung sebagai berikut:

$\mathrm{S}_{1}{ }^{+}=\left((2,7608-2,2086)^{2}+(2,1822-1,3093)^{2}+(3,2547-1,9528)^{2}+(2,5-2,5)^{2}\right)^{1 / 2}=1,6618$

$\mathrm{S}_{2}{ }^{+}=\left((2,7608-2,2086)^{2}+(2,1822-1,3093)^{2}+(2,6038-1,9528)^{2}+(2,5-2,5)^{2}\right)^{1 / 2}=1,2209$

$\mathrm{S}_{3}{ }^{+}=\left((2,2086-2,2086)^{2}+(1,3093-1,3093)^{2}+(1,9528-1,9528)^{2}+(2,5-2,5)^{2}\right)^{1 / 2}=0$

$\mathrm{S}_{4}{ }^{+}=\left(\left(2,2086-2,2086^{2}+(2,1822-1,3093)^{2}+(1,9528-1,9528)^{2}+(2,5-2,5)^{2}\right)^{1 / 2}=0,8729\right.$

5. Menentukan nilai kedekatan untuk setiap alternatif.

Nilai kedekatan diperoleh dengan menghitung sebagai berikut :

$$
\begin{aligned}
& \mathrm{P}_{1}=\frac{1,6618}{0+1,6618}=1 \\
& \mathrm{P}_{2}=\frac{1,2209}{0,6509+1,2209}=0,6522 \\
& \mathrm{P}_{3}=\frac{0}{1,6618+0}=0 \\
& \mathrm{P}_{4}=\frac{0,8729}{1,4141+0,8729}=0,3817
\end{aligned}
$$

Untuk hasil penilaian dapat dilihat pada tabel 8 dan dapat disimpulkan alternatif yang paling cocok dan direkomendasikan adalah A1.

Tabel 8. Hasil Penilaian

\begin{tabular}{|l|l|l|}
\hline Ranking & Alternatif & Keterangan \\
\hline 1 & A1 & Nasi Goreng Ayam \\
\hline 2 & A2 & Nasi Bakar Ayam \\
\hline 3 & A4 & Nasi Kuning \\
\hline 4 & A3 & Nasi Uduk \\
\hline
\end{tabular}

\section{Tampilan program}

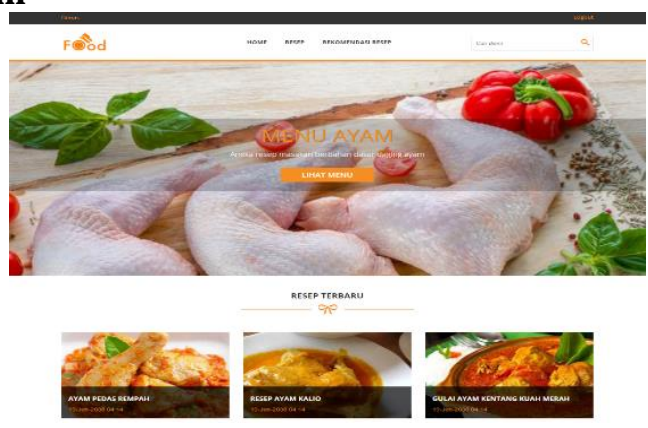

Gambar 3. Menu Utama 


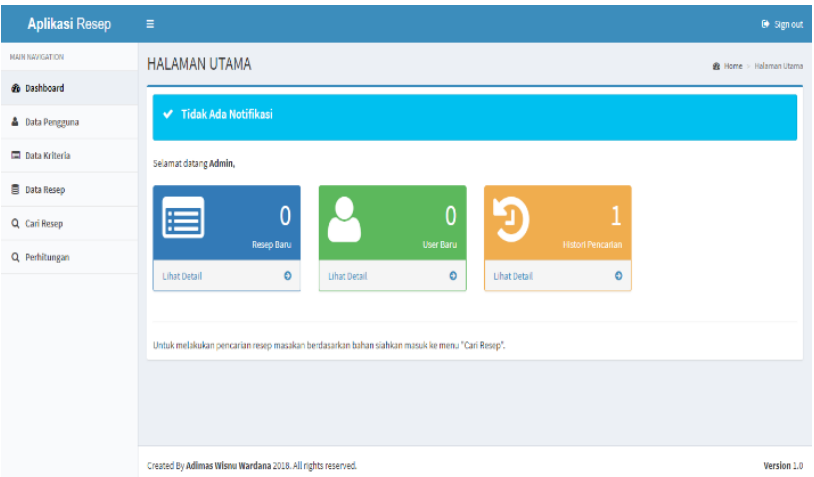

Gambar 4. Halaman Utama Admin

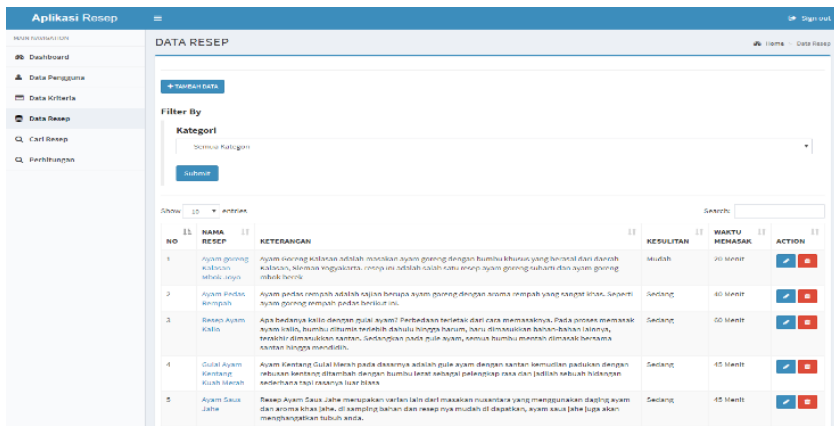

Gambar 5. halaman data resep admin

\section{HASIL DAN PEMBAHASAN}

Pengujian sistem dilakukan dengan cara penulis mencoba langsung pada aplikasi ini sesuai dengan masukan data kriteria yang telah ditentukan. Sedangkan penilaian manual dilakukan dengan cara penulis membandingkan dan mencocokan detail informasi dari setiap resep makanan yang diuji dengan data kriteria yang telah ditentukan dan kemudian diseleksi hingga terpilih resep makanan dengan nilai tertinggi yang dinilai berdasarkan 4 (empat) kriteria.

Tabel 9. Data Testing

\begin{tabular}{|c|c|c|c|c|c|c|c|}
\hline \multirow[b]{2}{*}{ No } & \multirow[b]{2}{*}{$\begin{array}{c}\text { Daftar Resep } \\
\text { Makanan }\end{array}$} & \multirow{2}{*}{$\begin{array}{c}\text { Bahan } \\
\text { Makanan } \\
\text { Tersedia }\end{array}$} & \multirow{2}{*}{$\begin{array}{c}\text { Tingka } \\
\mathrm{t} \\
\text { Kesuli } \\
\tan \\
\text { yang } \\
\text { Dipilih }\end{array}$} & \multirow{2}{*}{$\begin{array}{l}\text { Waktu } \\
\text { Memas } \\
\text { ak yang } \\
\text { Dipilih }\end{array}$} & \multicolumn{2}{|c|}{$\begin{array}{c}\text { Resep Masakan } \\
\text { dengan Nilai Tertinggi }\end{array}$} & \multirow[b]{2}{*}{ Ket } \\
\hline & & & & & $\begin{array}{c}\text { Penilaian } \\
\text { Manual }\end{array}$ & Sistem & \\
\hline 1 & $\begin{array}{ll}\text { a) Ayam Budu } \\
\text { Budu } \\
\text { b) Ayam Goreng } \\
\text { Sederhana } \\
\text { c) Sapi Goreng } \\
\text { d) Daging Sapi } \\
\text { Kecap } \\
\text { e) Ayam Goreng } \\
\text { Padang }\end{array}$ & $\begin{array}{l}\text { a) Daging } \\
\text { Ayam } \\
\text { b) Daging } \\
\text { Sapi } \\
\text { c) Bawang } \\
\text { Merah } \\
\text { d) Bawang } \\
\text { Putih } \\
\text { e) Cabai } \\
\end{array}$ & $\begin{array}{l}\text { Sedan } \\
\mathrm{g}\end{array}$ & Semua & $\begin{array}{l}\text { Daging } \\
\text { Sapi } \\
\text { Kecap }\end{array}$ & $\begin{array}{l}\text { Daging } \\
\text { Sapi } \\
\text { Kecap }\end{array}$ & $\begin{array}{l}\text { Sesua } \\
\text { i }\end{array}$ \\
\hline 2 & $\begin{array}{l}\text { a) Ayam Budu } \\
\text { Budu } \\
\text { b) Ayam Goreng } \\
\text { Sederhana } \\
\text { c) Sapi Goreng } \\
\text { d) Daging Sapi } \\
\text { Kecap }\end{array}$ & $\begin{array}{l}\text { a) Daging } \\
\text { Ayam } \\
\text { b) Bawang } \\
\text { Merah } \\
\text { c) Bawang } \\
\text { Putih } \\
\text { d) Kemiri }\end{array}$ & Semua & Semua & $\begin{array}{l}\text { Ayam } \\
\text { Goreng } \\
\text { Sederhan } \\
\text { a }\end{array}$ & $\begin{array}{l}\text { Ayam } \\
\text { Goreng } \\
\text { Sederhan } \\
\text { a }\end{array}$ & $\begin{array}{l}\text { Sesua } \\
\text { i }\end{array}$ \\
\hline
\end{tabular}




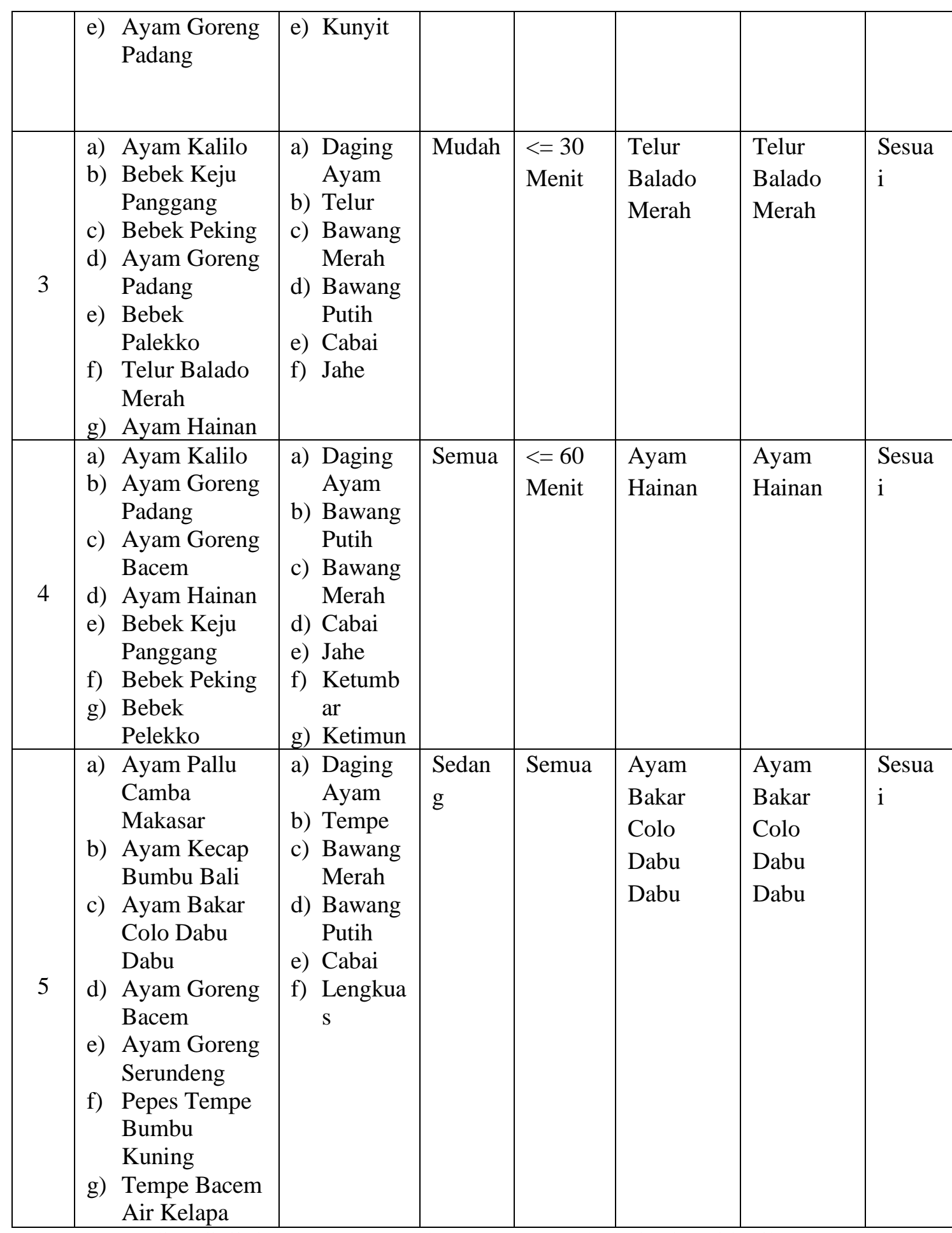

Kemudian diuji dengan menggunakan presentase akurasi sebagai berikut :

Terdapat 8 data sesuai dan 2 data tidak sesuai dari total 10 data yang diuji coba, maka diperoleh akurasi sistem sebagai berikut :

$$
\text { Prosentasi }=\frac{8 \times 100 \%}{10}=80 \%
$$

Dari pengujian di atas dapat disimpulkan bahwa tingkat keakurasian sistem adalah $\mathbf{8 0 \%}$.

\section{KESIMPULAN}

Dengan menerapkan metode TOPSIS telah dapat dibangun sebuah aplikasi SPK untuk membantu menentukan rekomendasi resep makanan berdasarkan bahan makanan. Hasil dari 
sistem pengambilan keputusan berupa perankingan resep makanan yang diperoleh dari perhitungan nilai TOPSIS. Dari total 10 data yang telah diuji coba dalam implementasi sistem, 8 data dinyatakan sesuai sedangkan 2 data dinyatakan tidak sesuai, sehingga tingkat akurasi dari sistem ini sebesar $80 \%$.

\section{Daftar Pustaka}

[1] Wikibuku. (2012). Resep. https://id.wikibooks.org/wiki/Resep (diakses pada tanggal 30 Desember 2017)

[2] Nabila, Ratih Kartika Dewi, Komang Candra Brata (2016). Sistem Pendukung Keputusan Pemilihan Resep Masakan dengan SAW dan Fitur Berbasis Lokasi pasa Android, Jurusan Teknik Informatika Universitas Brawijaya.

[3] Morton, Michael S. Scott. (1970). Management Decision Systems. New York : Harvard University Press

[4] Surbakti, Irfan. (2002). Sistem Pendukung Keputusan (Decision Support System). Surabaya : Jurusan Teknik Informatika Fakultas Teknologi Informasi Institut Teknologi Sepuluh November

[5] Turban, Efraim, Jay E, Aranson, \& Liang, Ting Peng. (2005). Decision Support System And Intelligent System I. Yogyakarta : Andi

[6] Yoon, K. Dan Hwang, C.L. (1981). Multi Attribute Decision Making: Methods and Applications. New York : Springer Verlag

[7] Kustiyahningsih, Yeni \& Ananisa, Devie Rosa. (2011). Pemograman Basis Data Berbasis Web Menggunakan PHP dan MySQL. Yogyakarta : Graha Ilmu

[8] Oetomo, Budi Sutedjo Dharma. (2002). Perencanaan dan Pembangunan Sistem Informasi. Yogyakarta : Andi

[9] Hartono, Jogiyanto. (1999). Analisis dan Disain Sistem Informasi : pendekatan terstruktur teori dan praktek aplikasi bisnis. Yogyakarta : Andi

[10] Likert, Rensis. (1932). PA Technique for the Measurement of Attitudes. Archives of Psychology 22(140) 1-55 